\title{
Microgram per Second
}

National Cancer Institute

\section{Source}

National Cancer Institute. Microgram per Second. NCI Thesaurus. Code C85705.

Micrograms per second. 